\title{
The ecological footprint and the evolution of some Roman sites on the Danube River
}

\author{
D. Constantinescu \& A. B. Carlan \\ University Politehnica of Bucharest, Romania
}

\begin{abstract}
In the present paper the authors are following up previous studies regarding the Roman defence sites along the Danube River and the influence of the environmental changes on their evolution. Ancient roman military and civilian buildings are relevant examples of the manifold sites, which were included in the economic and defensive system of the Roman Empire. There are many witnesses confirming the strength and complexity of these architectures, but, at the time, they were partially or totally destroyed. An important factor may be considered the defensive function, but it is not enough. Other important elements explaining the degradation of the sites may be considered to be environmental and climatic changes as well as the ecological footprint. Developing these hypotheses, along with studying the historical documents, the authors have discovered data about the dynamism, traditions and culture of the analysed sites. The comparisons with similar sites located on the Rhine River are also of interest. An innovation proposed in the article is the evaluation of the material and energy capacities, using specific engineering and technical instruments, which may be an important application in the determination of the ecological footprint. Particular kinds of energy and material resources are evaluated in correlation with the informational feedback using the theory of the systems as an analytical tool. It is proposed to explore the particularities of this challenging and enigmatic example of the European patrimony, attending the outlook of the ecological parameters.

Keywords: Roman, defence site, environment, changes, energetic balance, consumption, ecological fingerprint, footprint, Danube.
\end{abstract}




\section{Introduction}

While exploring ancient historical sites, there is a chance to espy some new aspects, which may change actual conceptions and attitudes. Remarkable differences between what is known (regarding the traditions and beliefs and the reality) may exist. It is often possible to examine a large number of aspects which may change our initial assumptions and points of view. We have to remark that the present article, similar to previous articles, does not have the scope to establish some historical events [1]. It is simply attempting to put forward questions, and proposes some explanations, from an environmental point of view, regarding the evolution of fascinating and little known historical sites along the Danube River.

During the time, the evolution, the increase and decrease until the disappearance of the Daco-Roman establishments along the Danube may be explained not only by geo political events, but also by economical and climatic evolutions, interrelated with the environmental situation. The dual impact of the historical defence sites and the environment in addition to human activities in such ancient settlements is certainly remarkable. The problem was tackled by studying the interconnections using the 'ecological footprint' method and applications of dynamical systems theory, because it is necessary to have in view the global evolutions.

The study focused especially on the sites along the middle and lower Danube, like Sucidava (Romania) and Ulpia Oescus (Bulgaria), coupled due to their position alongside the river. These two sites had a good communication system (Figure 1) through the bridge constructed on the orders of Constantine the Great [1], in the fourth century. Defence sites like Capidava and Argamum were also analysed (Figure 2).

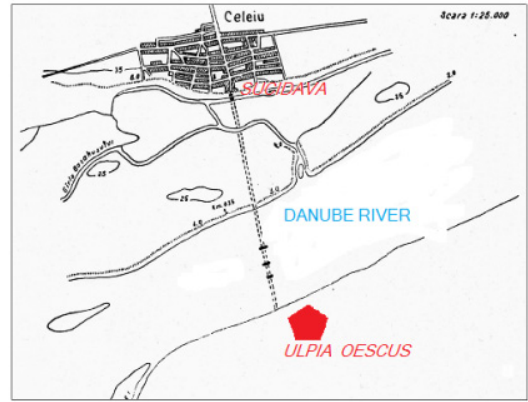

Figure 1: Location of Sucidava (434ㄴ'N; 2430’E) and Ulpia Oescus.

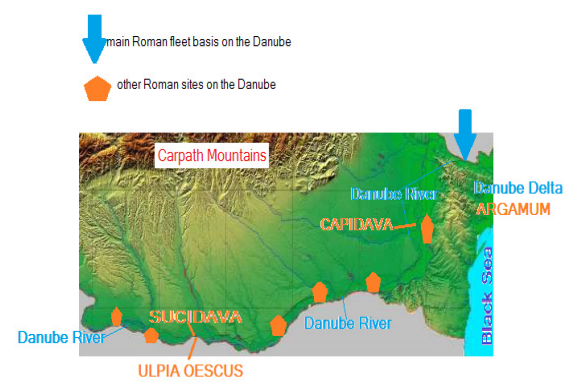

Figure 2: Position of some Roman defence sites on the Danube River.

One should not be surprised by certain distinct similarities between sites located at a considerable distance from each other, which will be discussed later.

Figure 3 presents the general schema for research regarding the evolution of the historical defence sites. We have started to work on the basis of this plan, which will also be the plan for future research. 


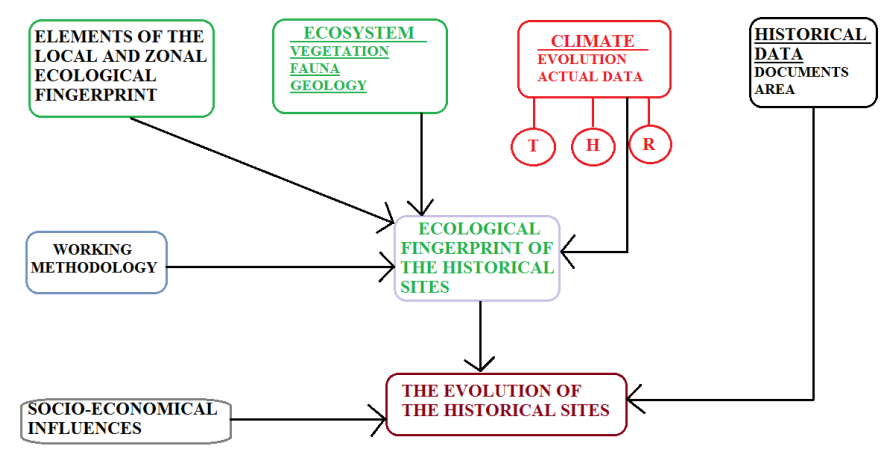

Figure 3: Influences on the evolution of the historical defence sites (for the climate: $\mathrm{T}$ - temperature; $\mathrm{H}$ - humidity; $\mathrm{R}$ - radiations).

\section{Methodology}

It is important to understand the approach and intensity of all factors that influenced, during the time, the evolution of defence sites, along the Danube. The climate changes are included in this historical framework, so an analysis on this field has been carried out, in order to find new information regarding the activities in the sites. To answer this problem, first of all the special literature was studied (e.g. Karagiorgu [2], Pârvan [3], Toropu [4]) and publications containing the exploration results of important historiographers (e.g. Tudor [5, 6], Pârvan [7]). Concurrent to this were also extracted the appropriate elements that may be used to calculate the ecological footprint and the applications of the dynamical systems theory.

Secondly, there were expert expeditions to the sites taken for the study (Sucidava, Ulpia Oescus, Capidava, on the Danube River, Argamum at the Black Sea and Augusta Raurica on the Rhine River), the purpose of which was to realise measurements and analyses on the land. The obtained data were applied in mathematical models, in order to calculate energy and material balances, the main instruments proposed to start the evaluation of the ecological footprint. The 3rd step in this phase of the activities, applying information on the scope of mathematical analysis using the energy balance, material balance and measurements on the area of the fortress Sucidava, some useful data were obtained for the evaluation of the ecological footprint. A physical model was also realised, containing the defence towers and enclosure walls. It is the manner of developing the architecture of roman buildings, the structure of their constructions and their military strategies in wars.

\subsection{Application of the ecological footprint}

World Wide Fund for Nature (WWF) began its Reports about the footprint in 1998 to show the state of the natural world and the impact of human activity upon it [8]. Since then, they continuously publish reports, refining and developing measures of the state of the Earth. A huge number of data are used. The data refer especially to a period of the last 50 years. 
Similar analyses were not done for the historical period. One of the problems is the difficulty to access some similar data.

The latest available data indicate that humanity's ecological footprint, our impact upon the planet, has more than tripled since 1961, as presented in WWF reports [8]. Our footprint now exceeds the world's ability to regenerate by about 25 per cent. But similar pressures, on smaller areas, were produced during history. It is possible that this pressure has influenced development and contributed to evolution and then to the involution of the historical sites.

The consequences of the pressure on Earth's natural systems, on the environmental systems are both predictable and dire. The other possible index to be used is the "Living System Index". It may show a rapid and continuing change of biodiversity - populations of fauna and vegetal species. The declined index during the analyzed historical period (years 100 ..600) may offer some explanations of the decline of human settlements. This confirms previous trends.

Following the proposals of Wackernagel and Rees [9], we consider that the evaluation of the ecological footprint in the case of historical sites supposes as a first step the establishing of energy and material fluxes at the level of the ecosystem. Most of the fluxes can be converted to equivalent surfaces of soil or superficial water. Finally, these are supposed to express the necessary surface of soil and water. We may refer to individual, local, zonal or global ecological footprints.

With some particularities, the following equation can be used:

$\mathrm{E}_{\mathrm{F}}$ : ecological footprint;

$$
E_{F}=\frac{P}{Y N} \times Y F \times E_{Q F}
$$

P : quantity of the used resources or of the generated rejection;

YN: local or zonal average value of the used resource P (or, if the case, the rejections);

YF: estimated output factor for the evaluated activity;

$\mathrm{E}_{\mathrm{QF}}$ : factor of equivalence.

The indicator of "bio-capacity" or "living system index" is a second useful factor when analyzing the impact of the site on the environment. This factor refers to the capacity of an ecosystem to produce resources and to recycle rejections. It may be expressed by a ratio between global (or zonal) surface and the global (or zonal) production: "hag" (global hectares) or "haz" (zonal hectares). In our study we will refer to the "zonal hectares". This indicator depends on the local natural conditions and on the technologies used not only for agriculture and use of forestry, but also for energy resources. It can be evaluated with:

$$
B_{C}=S \times Y F \times E_{Q F}
$$

S: available surface for a dedicated usage of the land.

The factor "YF" refers to the usage of the land in comparison with the average value for the historical period that we are referring to (years 100 ....600 A.D.). $\mathrm{E}_{\mathrm{QF}}$ factor represents a conversion factor of the use of all the lands (soils) taking into consideration their input on the ecological footprint.

The ecological footprint, $\mathrm{E}_{\mathrm{F}}$, has to be reported to the bio-capacity or to the living index $\mathrm{B}_{\mathrm{C}}$ to have a correct view of the situation. 
We currently do not have historical data about the $\mathrm{E}_{\mathrm{QF}}$ factor; therefore we propose to apply the factors offered by "The World's Ecological Footprint and Bio-capacity".

\subsection{Measurements and observations on the land}

Over time, the ruins of Sucidava, Ulpia Oescus, Capidava and Argamum have undergone a process of progressive degradation, caused not only by nature but also by man. Without doubt over the centuries many parts of the stones and bricks used initially for the construction of the walls or for the buildings of ancient cities and defence fortresses were reused for other constructions. Figures 4 and 5 present the remains of the defence sites Sucidava and Ulpia Oescus today. Figures 6 and 7 present similar images for the defence sites from Capidava and Argamum.

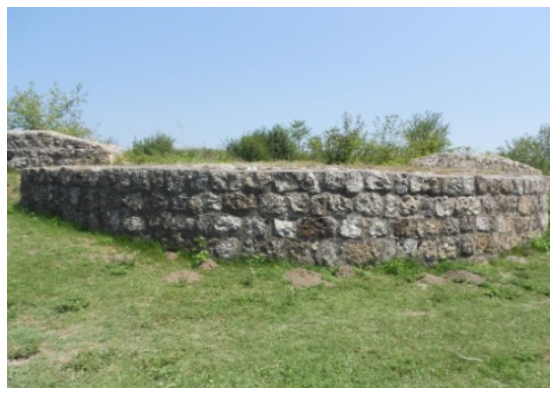

Figure 4: Defence wall and circular tower at Sucidava sites (photo: D. Constantinescu, August 2013).

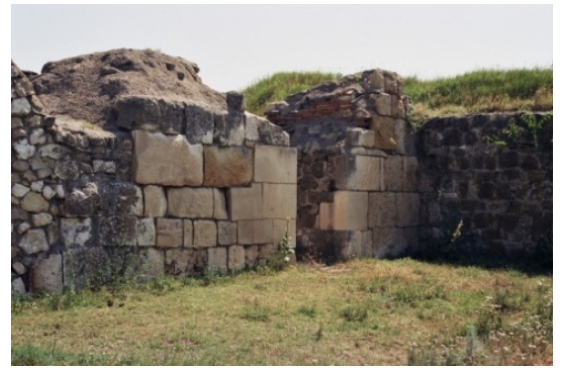

Figure 6: Structures of internal walls of Capidava defence site (photo: D. Constantinescu, May 2012).

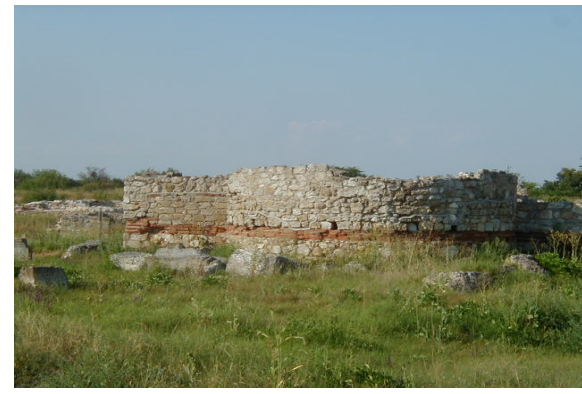

$\begin{array}{ll}\text { Figure 5: } & \begin{array}{l}\text { Defence walls and } \\ \text { circular tower at Ulpia }\end{array} \\ & \text { Oescus (photo: D. } \\ \text { Constantinescu, August } \\ \text { 2013). }\end{array}$

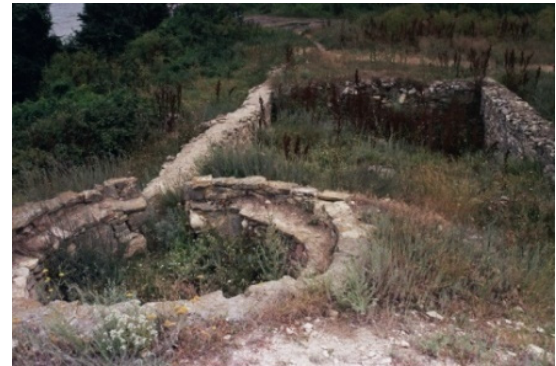

Figure 7: Defence wall and tower of not totally explored sides of Greek-Roman fortresses near the Black Sea, Argamum (photo: D. Constantinescu, May 2012). 
Many problems regarding the environment and the constructions are similar for the analysed sites - Augusta Raurica [10], Sucidava, Capidava and Argamum [11]. It seems that Capidava was one of the biggest roman fortress (castrum) included in the defensive system of the Roman Empire on the Danube, located at a strategic point, on the top of a rock (Figure 8 - aerial view of the Capidava, Figure 9 map of the defence site). For the fortresses Sucidava and Capidava we have taken measurements of the walls and interior buildings for a preliminary calculation of the ecological footprint (Figures 10 and 11).

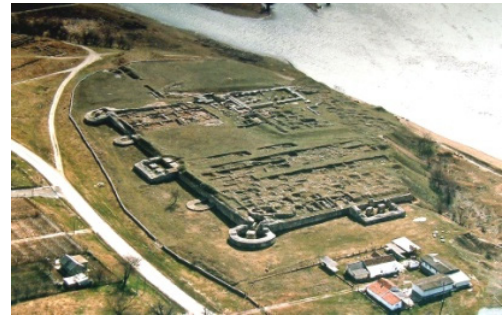

Figure 8: Castrum Capidava, aerial view, August 2002.

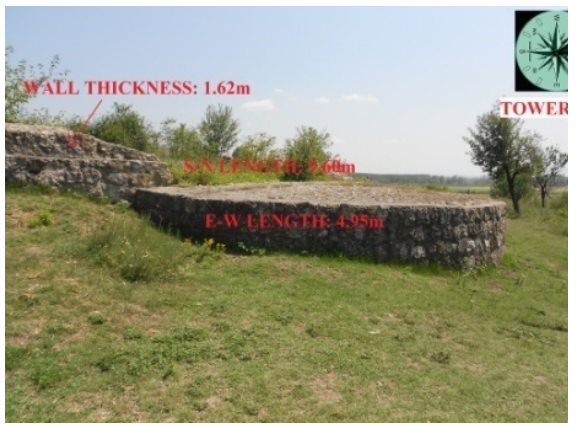

Figure 10: Dimensions of the circular tower "C" and E-W wall (Sucidava fortress, on Danube) (photo: A.B. Carlan, October 2013).

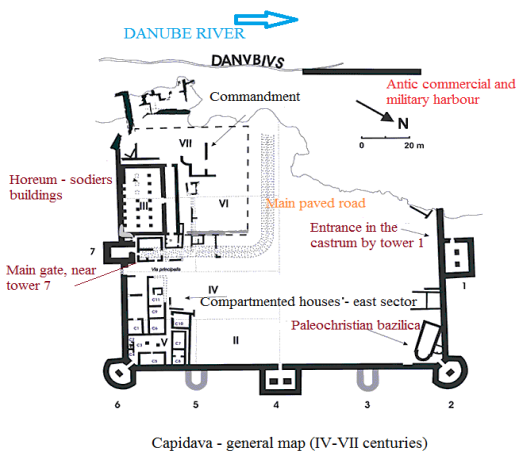

Figure 9: Map of the castrum Capidava (note: from 1 to 7 defence towers).

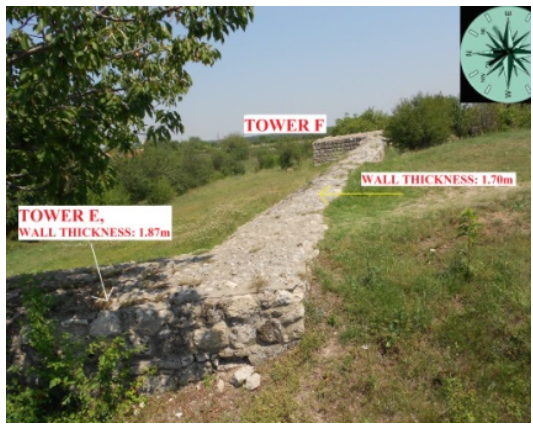

Figure 11: Defence wall and towers "E" and "F" (Sucidava fortresses, on Danube) (photo: A.B. Carlan, October 2013).

\subsection{Ecological systems as dynamic systems}

Studying the aspects of the ecological footprint in the zones along the Danube River, which corresponds to the roman fortification system, we propose to also 
take into account the dynamic aspects of the ecological systems. The general aspect of a "historical site system - ecological system" complex may be systematized, as shown in Figure 12.

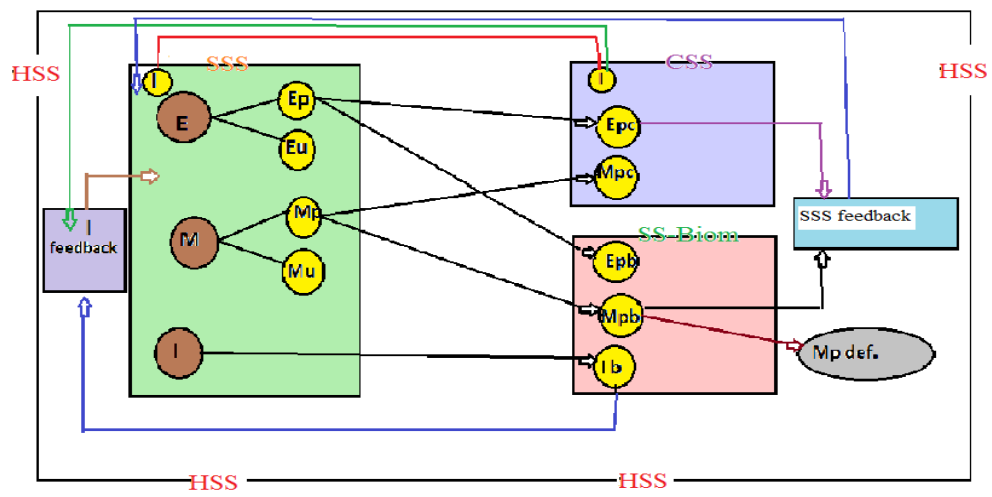

Figure 12: Dynamic system HSS (Historical Site System) including: SSS (Sucidava or Capidava or another historical site), CSS - climatic subsystem, SS Biome - subsystem; E - energy, M - materials, I information; $\mathrm{p}-$ lost, $\mathrm{u}$ - useful, def - definitively lost.

\subsection{Impact of climate changes}

The climate has a considerable influence on the evolution of the defence sites. The climate parameters like temperature, humidity, winds, solar radiation influence energy consumption (in our case the energy resource was wood), as well as agriculture, transport, utilisation of the materials and even the social, political and military relations. In many documents, it is mentioned that in years 100-600 the climate was colder than today. For example, Pârvan mentions repeatedly in his studies [7] a very cold period, especially during the winters. The Danube was normally frozen every year for a long period of time. We need to know exactly the climate parameter, in order to calculate the energy and material consumption, but sometimes the data are not very accessible. Some indications for the values of the temperature, from the article of Moberg et al. [13] are presented in Figure 13. We will try to use the value resulting from this observation to compute the necessary energy consumption in the historical sites that we analyze.

\section{Comparison between the analysed historical defence sites}

Connections in the Roman Empire were very good, using as a system of communication the rivers or the terrestrial roads. In a previous article [1] some of these connections are presented. "Tabula Peutingeriana" shows the terrestrial roads (itinerarium), using "cursus publicus" (the state-run courier and transportation service of the Roman Empire, later inherited by the Byzantine Empire. On the maps of "Tabula Peutingeriana" some "itinerarium" can be 


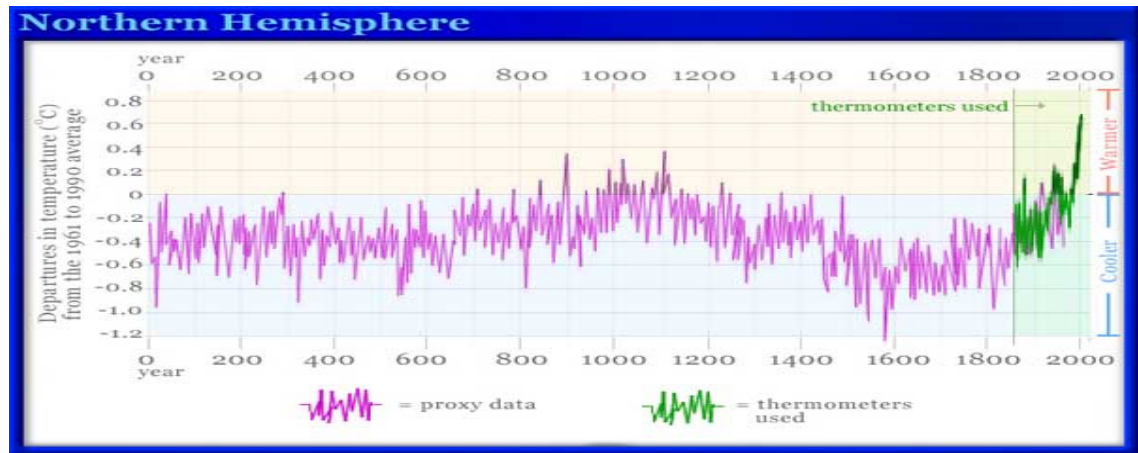

Figure 13: Graph of the temperatures based on data reported by Moberg et al. in Nature, V. 433, 10 February 2005.

observed, as for example the connection between Ulpia Oescus - Sucidava and the possible road to Augusta Raurica, by Transylvania [12]. In any case, the shortest way from Gallia to the Danube was the Rhine. This is an argument to explain the similarities, including architectural aspects, between the Roman colonies and especially between the new established sites in the centuries I- IV.

Figure 14 presents the general map of the Sucidava roman establishment and Figure 15 shows the map of the fortification.

For "Ulpia Oescus", in an article from Archeologica Bulgarica, Boyanov [15] proposed the map presented in Figure 16. We have to mention some similarities regarding the constructions, similitude we can also find at Augusta Raurica [1]. For our calculation, we mention the presence of thermal installations, like the hypocaust and the hot bath. These buildings are not present on all the historical sites on the Danube.

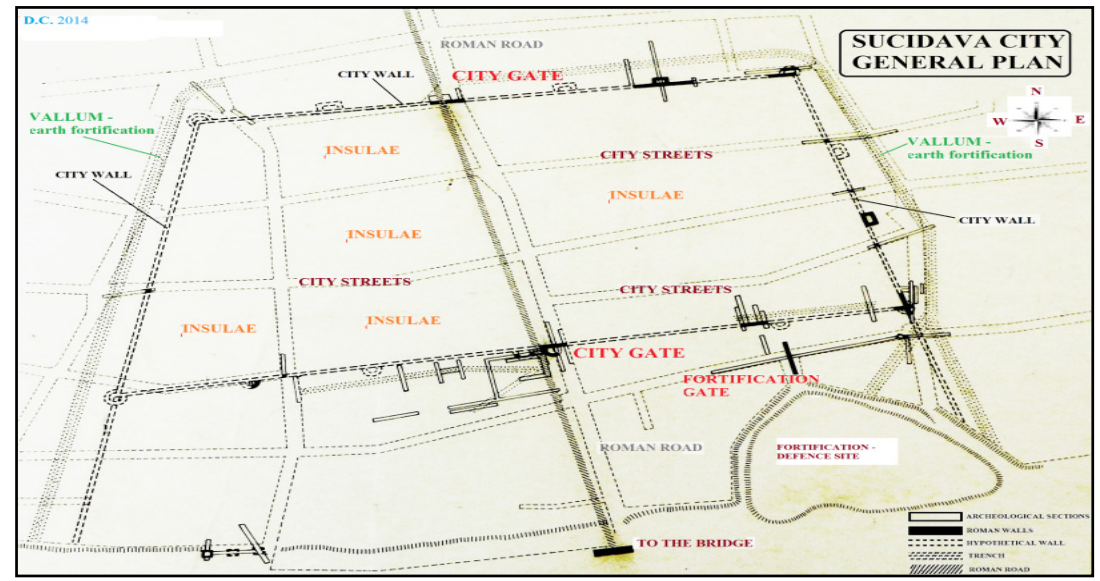

Figure 14: General plan of Sucidava site (reproduced from an ancient map from the local museum, D. Constantinescu). 


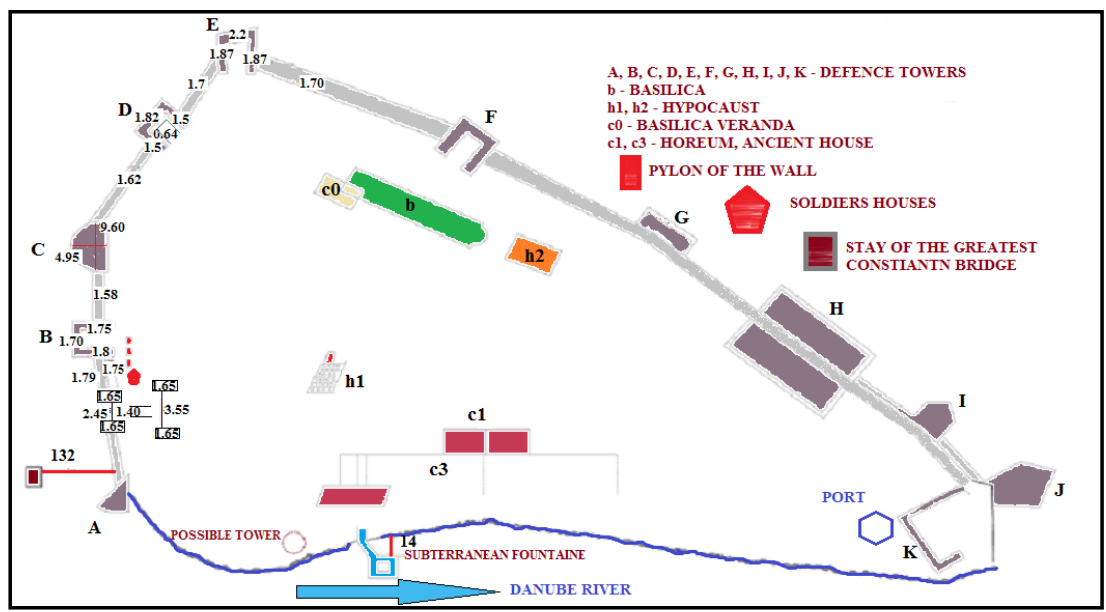

Figure 15: Plan of the Sucidava fortification (established using the "on land" measurements), A.B Carlan, 2014 (the numbers represent the wall dimensions).

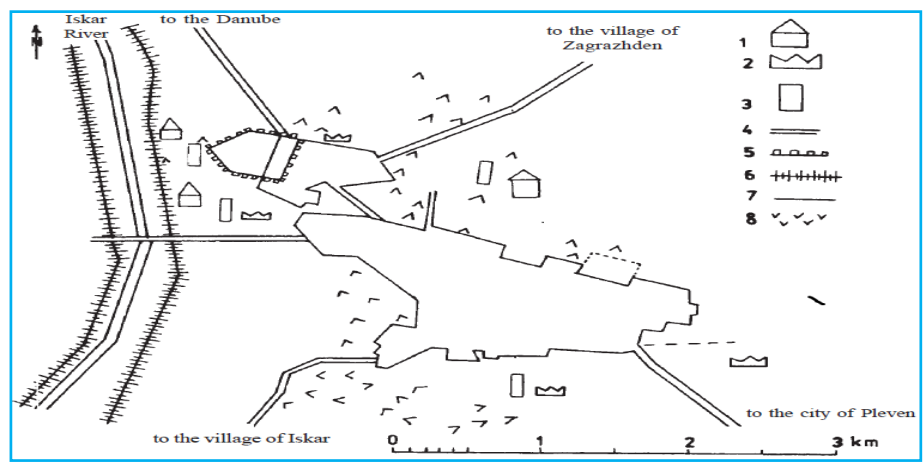

Figure 16: Map of Ulpia Oescus (after [15]). 1 - sarcophagi, 2 - sarcophagi's cover, 3 - graves, 4 - modern roads, 5 - fortified walls, 6 - dike, new regulation of Iskar River, 7 - border of the today village, 8 - swampy arrears.

If we compare the heating systems, we notice the similarities, as presented in Figures 17, 18 and 19-20. The energy source was wood in all cases. The nature of the wood depends on the location of the establishment. For example, in the case of Sucidava and Ulpia Oescus only oak was used. 


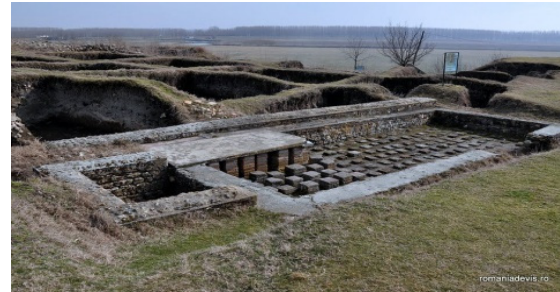

Figure 17: Heating system with "prefornum" at Sucidava (August 2011).

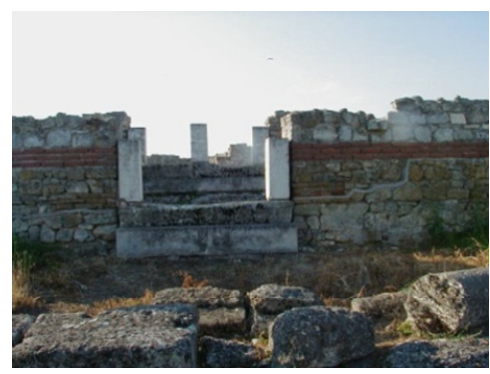

Figure 18: Entrance to the "thermae" at Ulpia Oescus (photo: D. Constantinescu, August 2013).

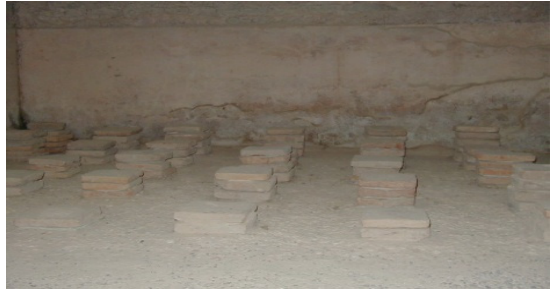

Figure 19: Heating system at the "thermae" from Augusta Raurica (October 2011).

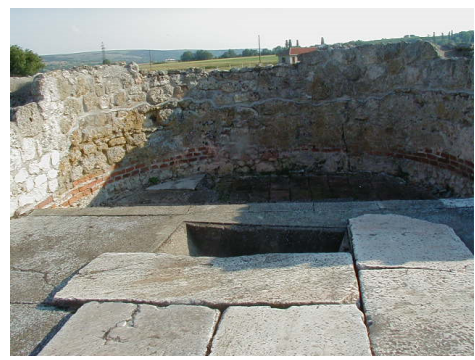

Figure 20: Hot water pool, thermae, Ulpia Oescus (photo: D. Constantinescu, August 2013).

\section{Case study: historical site Sucidava}

It seems that the "retreat" of the Roman Empire was well coordinated, occurring in the period from AD 250 to AD 270. Then, after a short period of about 250 years there was renewed activity, this is followed once again by a hiatus in the years AD 580-600. We try to explain that this retreat was not only from continuous attacks and the military situation, but also the interaction with the climate changes and the pressure on the environment. Therefore, the ecological footprint is used as an analysis instrument. Roman - byzantine cities and defence sites had an ecological impact on the environment since the beginning, because the constructions were made of wood and later in stone. Pârvan [7] mentions these aspects repeatedly in his works. The same aspects are mentioned for Augusta Raurica $[10,16]$. The wood was used for heating systems, for the constructions of citadels and houses, and also for the ordinariness of equipment, furniture and plates. The archaeological excavations in the mentioned site areas bring important data regarding the nature of the wood used for constructions, because the charred fragments that were discovered and exposed in The History Regional Museum of Pleven (Bulgaria) are oak. 
In order to evaluate the ecological footprint, we start by proposing the calculation of energy consumption, to evaluate the quantity of wood used by the Romans for the heating systems in the structure called the "hypocaust". Figures 21 and 22 present the aspect and the dimensions of this kind of construction.

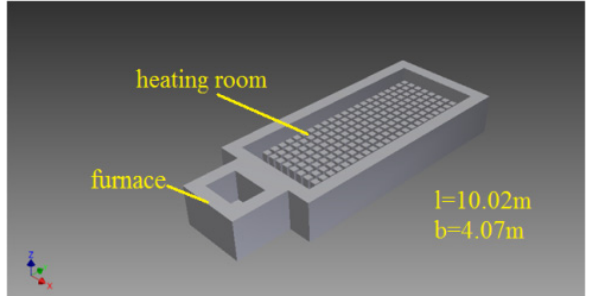

Figure 21: Reconstruction of hypocaust and furnace, Sucidava.

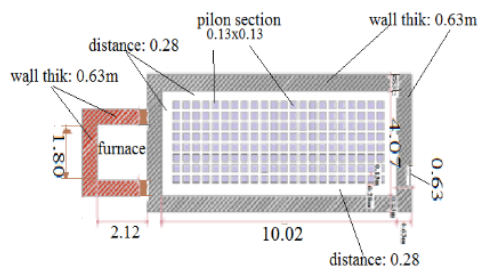

Figure 22: Hypocaust dimensions (in meters).

The yearly oak wood consumption for hypocaust 1 in Sucidava for the winter and summer seasons are presented in Table 1.

Table 1: Analysis of energy and wood (oak) consumption (height of rooms: $1.90 \mathrm{~m})$.

\begin{tabular}{|c|c|c|c|c|c|c|}
\hline $\begin{array}{l}\text { Floor } \\
\text { isolation }\end{array}$ & $\begin{array}{c}\text { Average } \\
\text { temp. } \\
{ }^{0} \mathrm{C} \\
\end{array}$ & $\begin{array}{c}\text { Oak wood } \\
\text { energy } \\
{[\mathrm{MJ} / \mathrm{kg}]}\end{array}$ & $\begin{array}{c}\text { Necessary } \\
\text { thermal flow } \\
{[\mathrm{GJ} / \mathrm{month}]}\end{array}$ & $\begin{array}{c}\text { Monthly } \\
\text { consumption } \\
\text { of oak [kg] }\end{array}$ & $\begin{array}{l}\text { Daily } \\
\text { consumption } \\
\text { of oak }[\mathrm{kg}]\end{array}$ & $\begin{array}{l}\text { Yearly } \\
\text { consumption } \\
{[\mathrm{kg}]}\end{array}$ \\
\hline \multirow[t]{4}{*}{ Wood } & $-15^{\circ} \mathrm{C}$ & \multirow{4}{*}{$\begin{array}{l}\text { a: } 14.4 \\
\text { (humid) }\end{array}$} & \multirow[t]{2}{*}{32.93} & a 5777 & a 192 & \multirow[t]{4}{*}{ a 30890} \\
\hline & winter & & & b 4450 & b 148 & \\
\hline & $+15^{\circ} \mathrm{C}$ & & \multirow[t]{2}{*}{2.45} & a 429 & a 14 & \\
\hline & summer & & & b 331 & b 11 & \\
\hline \multirow[t]{4}{*}{ Ceramic } & $-15^{\circ} \mathrm{C}$ & \multirow{4}{*}{$\begin{array}{l}\text { b:18.5 } \\
\text { (dry) }\end{array}$} & 23.71 & a 4233 & a 141 & \multirow[t]{4}{*}{ a 27660} \\
\hline & winter & & & b 3339 & b 111 & \\
\hline & $+15^{\circ} \mathrm{C}$ & & \multirow[t]{2}{*}{2.15} & a 377 & a 13 & \\
\hline & summer & & & b 302 & b 10 & \\
\hline
\end{tabular}

\section{Conclusion and discussion}

Over time, the ruins of sites like Augusta Raurica, Sucidava, Ulpia Oescus, Capidava, Argamum have undergone a process of progressive degradation, caused not only by nature but also by man.

Extensive damage was caused by invaders' fires, winds, rains and freeze-thaw. The earth covered and the weeds invaded the sites. 
Along with the appearance and development of settlements alongside the Danube and Rhine Rivers there occurred a massive intervention on local, natural resources. The exploitation of these resources, determined by the evolution of the historical sites, has led to the disturbance of the ecological equilibrium and modification of the ecological footprint values.

The paper tries to analyse the actual discovered data by the authors, and to offer the possibility to determine the ecological footprint, in the zone of the Danube historical sites. The methods of analysis are based on the study of existing historical documents, on the evaluations regarding climate evolution in the analysed period (sec. I-VI) and on studies "on land".

In the article were taken in view especially data about Sucidava establishment, but there were evaluations made on the sites Capidava, Argamum, Ulpia Oescus. We also used information from the Augusta Raurica site, along the Rhine River.

Numerous similarities were observed between these historical sites' evolution.

An ecological footprint study is effectuated by the evaluation of energy and material consumption, taken from local existent resources. We are proposing to continue the investigations regarding the ecological footprint for historical sites Capidava, Ulpia Oescus and Argamum. The obtained results will furnish conclusions about the role of the ecological footprint in the Lower Danube zone.

\section{References}

[1] Constantinescu, D. "Roman Defence sites on the Danube River and environmental changes", "Structural Studies, Repairs and Maintenance of Heritage Architecture XIII", series volume 131, WIT press 2013, http://www.witpress.com/978-1-84564-730-8.html eISBN: 978-1-84564731-5; ISSN: 1746-4498 (print); ISSN: 1743-3509 (on-line); Paper DOI: 10.2495/STR130471.

[2] Karagiorgu, O., "LR2 a Container for the Military annona, on the Danubian Border”, chap. 7 pp. 129-156 http://egg.mnir.ro/pdf/Karagiorgou Container.PDF

[3] Pârvan, V.,: Stiri nouă din Dacia Malvensis, Academia Română, Analele A.R. - Tom XXXVI, Mem. Sect. Istorice, nr.2, 1913 http://www.cimec.ro/ Biblioteca-Digitala/Parvan/ParvanStiriNouaDdinDaciaMalvensis.htm? filename $=$ ParvanStiriNouaDinDaciaMalvensis.pdf

[4] Toropu, O., Tatulea, C.: Sucidava - Celei, Edit. Sport-Turism, Bucharest 1987 pp. 219-225.

[5] Tudor, D.: Une cite daco-romaine et Byzantine en Dacie, Bruxelles Berchem, 1965, 140S., XXX S, Abb. $8^{\circ}$

[6] Tudor, D., Découvertes archéologiques à Sucidava et dans les environs, A.O., XVI, 1936.

[7] Pârvan, V., "Getica" - in "Memoriile secţiunii istorice", Academia Română, seria III, tomul III, Cultura Naţională, Bucureşti 1926, pp. 112804.

[8] World Wide Fund for Nature, "Living Planet Report 2006”, Gland, Switzerland, ISBN 2-88085-272-2. 
[9] Wackernagel, M., Rees, E.: “L'impronta ecologica. Come ridure l'impatto dell'uomo sulla Terra”, Edizioni Ambientale, Italy, 2008, ISBN 978-8889014-83-7.

[10] Pfäffli, B., "Petit guide d'Augusta Raurica”, publication Werner Druck AG, Basel, Switzerland, 2010, ISBN 978-3-7151-4007-0

[11] Manucu-Adameşteanu, M.,“Orgame/Argamum”, Edit. Tipored, Bucureşti 2001.

[12] Moberg, A., Sonechkin, D., Holmgren, K., Datsenko, N., Karle, W.,: "Highly variable Northern Hemisphere temperatures reconstructed from low- and high-resolution proxy data", Nature, V. 433, 10 February 2005, p. 13 .

[13] Moberg, A., Sonechikin, D., Holmgren, K., Datsenko, N., Karlen, W., "Highly variable Northern Hemisphere temperatures reconstructed from low- and high-resolution proxy data”, Nature, V. 433, 10 February 2005, p 613.

[14] http://www.euratlas.net/cartogra/peutinger/7_thracia/thracia_4_1.html 1

[15] Boyanov, I., "Oescus - from Castra to Colonia”, Arheologica Bulgarica, vol. XII, nr 3, Sofia 2008, pp. 69-7.

[16] Belard-Laur, R.: Guide d'Augusta Raurica, Edit: Historische und Antiquarische Gesellschaft, Bâle, 5-eme edition 1991, ISBN 3-71515002-5. 